resistance acquired by trypanosomes resulting from underdosing with 'Antrycide'.

In Kenya he started an insecticidal tsetse eradication scheme in the Nyando river basin near Lake Victoria, in collaboration with the Tropical Pesticide Research Institute. This project was to have far-reaching effects on the sleoping sickness problem in that country, for it was the first successful large-scale residuol insecticidal project undertaken against Glossina in East Africa.

When he went to Nigeria ho immediately recognized the urgent necessity of 'Nigerianizing' his department and began at once to do so. Again, with his characteristic foresight and drive, he lost no time in forming a Veterinary Tsetse and Trypanosomiasis Unit, staffing it with the best men he could find, and sent an officer to Kenya to examine the methods in use there. The next step was the Komadugu Ghana scherne, the biggest, boldest, most successful and cheapest residual insecticidal spraying operation ever undertaken against the tsetse flies Glossina morsitans sub. morsitans Newstead and G. tachinoides Westwood in the Sudan zone of Northern Nigeria. This work was followed up by even larger schemes and to-day the Northern Nigerian Veterinary Tsetse and Trypanosomiasis Unit ranks among the best and most up-to-date organizations of its kind in Africa. In rocognition of his outstanding services ho was awarded the C.B.E. by Her Majesty the Queen.

Geoff Wilson was a man of many parts, and two years after his appointment as professor at Utrecht he gave an inaugural address ontitled "The Problems of Trypanosomiasis Control in Cattle in Africa", ending up by speaking for 10 minutes in the Dutch language. But he had lost his heart to Northern Nigeria, and through his influence the 'Zaria Project' involving a part of the Veterinary Faculty of the new Ahmadu Bello University, supported by Dutch aid, came into being.

Apart from his numerous sciontific interests and achieve. ments, Geoff was an accomplished sportsman. As a boy he played rugby for the Ulster Schools side and later won his boxing blue at Edinburgh - he was Scottish Universities Welterweight Champion for 1933-34.

Besides his wifo, Maureen, he leaves behind two sons and a daughter. His eldest son is a veterinarian following in his father's footsteps, for he has recently taken up a post with the East African Trypanosomiasis Research Organ. ization at Tororo in Uganda.

Geoff was Irish to the finger-tips - kind, generous and considerate to his friends and a thorn in the side of his enemies--he will be sorely missed.

P. E. GLOVER

\section{Prof. S. K. Allison}

Samuer Krng Aldison, director of the Enrico Fermi Institute for Nuclear Studies and the Frank P. Hixon distinguished service professor in the Department of Physias at the University of Chicago, died on September 15, 1965, in England.

Prof. Allison was serving as the United States delegate to the Plasma Physics and Controlled Nuclear Fusion Research Conference under the sponsorship of the International Atomic Energy Agency in Culham, near Oxford. He suffered an aortic aneurism on September 6, and underwent surgery at the Radcliffe Infirmary, Oxford. Death was attributed to a pulmonary embolism.

Allison was one of the best known and best loved of American seientists. Born in Chicago in 1900, the son of a Chicago public school principal, he was a product of the community of which the University of Chicago is a part. He was educated in the Chicago public schools, recoived his B.S. degree from the University of Chicago in 1921 and his Ph.D. degree two years later. Following a period as National Research Fellow at Harvard University (192325) and as Fellow at the Carnegie Institution (1925-26), he joined the faculty at the University of California,
Berkeley, but returned to the University of Chicago in 1930 after having achioved the rank of associate professor.

Allison's early researches at Berkeley and Chicago were in $\mathrm{X}$-rays. His major work involved the design and construction of a high-resolution double crystal spectrometer, its application to the measurement of the widths and intensities of $X$-ray lines, and to the experimental confirmation of the C. G. Darwin-P. P. Ewald dynamical theory of X-ray diffraction. The depth of his understanding of the field of X-rays is evident from the book he wrote jointly with A. H. Compton, $X$-rays in Theory and Experiment, a classic text in tho field.

His interest turned to nuclear physies during the middle 1930 's. He concentrated on the reactions among the light elements that could be examined with accelerators of relatively low energy. The Cockeroft-Walton accelerator which he built himself and operated with his students developed a maximum of $400 \mathrm{kV}$. He dubbed it Kevatron to emphasize its modest capabilities at a time when his associates were constructing machines in the million- and then the billion-volt range. Yet the Kevatron kept turning out a continuous stream of interesting research and a continuing succession of able graduate students. Much of the research which he carried out together with his students concerned precise measurements of the energy released in proton-induced reactions. In lator years this interest shifted to the reactions induced by heavier ions. He was particularly successful in developing sources of lithium ions. To pursue these reactions more extensively, he needed higher energy machines. The University made available to him its 2-MeV Van de Graaff, acquired originally for biological studies. In the end he obtained a 4-MeV machine with a grant from the National Science Foundation.

A subsidiary interest which grew into a major activity was the investigation of the energy loss of charged particles moving through gases. This developed into an extensive investigation of the mechanism of capture and loss of electrons by the ions, a subject that turned out to give important insights into plasma physies and the quest for ways to harness thermonuclear fusion. For these studies the Kevatron continued to play a central part until the end.

Allison's emergence into public life had its origins in the secret wartime enterprise that developed the atomic bomb. He began, in January 194l, to investigate the suitability of beryllium as a moderator of slow neutrons for the chain reaction. The work was done with a grant of 9,000 dollars, obtained from the U.S. Office of Scientific Research and Development. Writing about this later, he commented, "I remember being aghast at the ease with which this seemingly colossal sum was placed at my disposal". This work has remained of fundamental interest and serves now as the basis for certain major lines of nuclear reactor development. Although beryllium, because of its scar city, did not occupy a prominent place in the initial development of the chain reaction, Allison's early effort served to focus that development at the University of Chicago. His group at Chicago was joined by Fermi's Columbia group and Wigner's Princeton group when, in February 1942, the "Metallurgical Laboratory" was organized under the leadership of A. H. Compton to develop a method for producing plutonium as a possible material for the atomic bomb. It was this Laboratory, at the University of Chicago, that successfully achieved the first nuclear chain reaction in December 1942.

Allison liked to recall his role on the occasion of the first chain reaction experiment. He was the leader of the "suicide squad". It was his brawn, not his brain, he insisted, that qualified him to be entrusted with the ultimate, last-ditch measure. It was his idea to prepare a huge jug of cadmium solution, and he stood ready to pour it over the chain-reacting pile in the event of all other control mechanisms failing to operate.

The work of the Metallurgical Laboratory led directly to the large-scale production of plutonium, out of which 
the first nuclear bomb was construeted. Allison served in this project from its beginning until 1944. He served as director of the Laboratory during the final year of this period. He jested that his main job was to sign the huge stacks of blueprints and documents having to do with the construction of the great nuclear reactors at Hanford.

In November 1944, he went to the Los Alamos Laboratory to work more directly on the development of the atomic bomb. He served as ehairman of the Technical and Scheduling Committee which scheduled the final stages of the test of the first atomic bomb on July 16, 1945. He made history when his voice sounded across the New Mexico desert, counting off seconds to zero on that memorable dawn that witnessed the first nuclear explosion.

September 1, 1945, was the day on which the University of Chicago announced the formation of its new research institutes with Allison as the newly appointed director of the Institute for Nuclear Studies. Such luminaries as Enrico Fermi and Harold. Urey were already enlisted as members. It was on this occasion that Allison made what came to be known as "Sam's butterfly speech". He warned that if the exchange of scientific information was prohibited by military regulation, scientists in America would leave the field of atomic energy and devote themselves to such subjects as the colours of butterfly wings. The speech became the opening salvo in the campaign the scientists fought to prevent military control of the peacetime development of atomic energy.

He served as the first director of the Institute of Nuclear Studies (later renamed for Enrico Fermi) until his death, except for one five-year interlude. The Institute was devoted to the idea that physicists, chemists, and astrophysicists had complementary interests and could work together under one roof with mutual benefit. Under Allison's stewardship the Institute flourished. The seminars were brightened by such men as Fermi, Teller, Urey, J. Meyer, Wentzel, Chandrasekhar, Gell-Mann, and Dalitz. Many new ideas were developed, among them two that have already won Nobel prizes: radio carbon dating (W. F. Libby) and the nuclear shell model (M. G. Mayer).

Allison was awarded the Medal of Merit for his work on the atomic bomb: he was a founding member of the Board of Sponsors of the Bulletin of the Atomic Scientists. He was elected a member of the National Academy of Sciences in 1946 and served as chairman of its Physical Section from 1960 until 1963. He served as guest lecturer and adviser in nuclear physies matters on several occasions in Spain, in Argentina, and in the United Arab Republic.

Allison was a large man and his tall stature and silverywhite hair gave him a striking presence in any gathering among men. It was difficult to disturb his sense of equilibrium and he had an air of imperturbable calm that made doubly effective the sound common sense he could interpose at the propitious moment in colourful but clear and quotable language. He never failed to find a humorous side to every situation, however tense.

He enjoyed the life of teaching and research. He never lost an opportunity to work in the laboratory with his own hands. He had a natural talent and the requisite patience for making his apparatus work and he took a particular pride in displaying these skills to his students.

$\mathrm{He}$ was a man who asked little but gave much. His friends, colleagues and former students mourn their loss.

H. L. ANDERSON

\section{Dr. H. R. Lang}

Dr. Herbert Raphael Lang, who died suddenly on November 18 at the age of sixty-one, had been secretary of the Institute of Physics, and afterwards of the amalgamated body of the Institute of Physies and the Physical Society, since 1932. His connexion with the Institute went even further back than this and he was present as a schoolboy at the inaugural meeting in 1921. Lang read physics at the Imperial College of Science and Technology, and after his first degree continued as research student and demonstrator, gaining his Ph.D. for work on the investigation of the effect of temperature on the specific heats of liquids. His work on the thermal properties of liquids continued after his appointment to a research Fellowship by the Institute of Petroleum. He could have made an outstanding career in research or in industry but, fortunately for the physics profession, he was persuaded to become secretary of the Institute. It is difficult to imagine anyone better suited for such a post. Apart from his deep interest in physics he had a rare combination of wisdom, realism, determination and loyalty, as well as an enormous capacity for hard work, and above all a kindly and unselfish nature. No task associated with physics was too great or too small for him, whether it was organizing an international conference, forming a new subject group, giving professional advice to a junior colleague or operating the benevolent fund.

Lang was, by nature, shy and retiring. Although most members of the Institute and Society realized that he played a very large part in its affairs, it was only those who were privileged to work closely with him who fully appreciated the extent of his efforts and devotion. His work was conducted largely behind the scenes and he sought no personal credit. New developments and policies which were largely inspired by him were usually presented to the members through the honorary officers. At the same time, he was always ready to give credit to his own staff.

When Lang took office in 1932 the physics profession, as such, barely existed. To-day there are more than eleven thousand members, drawn from academic establishments, industry and government service. Under Lang's guidance, this vast number of pure and applied physicists, distributed throughout the United Kingdom and abroad, have developed, through the branches and specialist groups, common interests and activities, and a sense of belonging to the profession. From his early days in the Institute of Physics, Lang maintained close contact with the Physical Society, and it was due in no small measure to his untiring efforts during many years that amalgamation of the two bodies was effected in 1960 .

Physics owes much to Lang and he will be greatly missed. He leaves a widow and three sons.

\section{R. Gavin}

\section{W. B. Alexander}

W. B. Alexander, formerly director of the Edward Grey Institute of Field Ornithology, University of Oxford, died on December 18, 1965, at the age of eighty. He was educated at Bootham School, York, Tonbridge School, and King's College, Cambridge. The Cambridge degree ceremony then involved a procession, headed by the first-class honours men (in alphabetical order) from the college providing the Vice-Chancellor, and in 1909 it was led by W. B. Alexander and the man he referred to as 'young Brooke'. After brief appointments in the Cam. bridge Museum of Zoology and then as assistant naturalist to the Board of Fisheries (North Sea), he accepted, in 1912, the post of assistant in the Western Australian Museum, Perth, and was Keeper of the Biological Department there from 1914 to 1919 (apart from two years in Melbourne on war work as a science abstracter). In this period he revitalized the Perth museum. After a brief return to England, he was biologist to the Prickly Pear Board from 1920 until 1925, and thus a prominent member of the team which effected one of the most successful examples of biological control of a pest ever recorded. Alexander being the man who first brought live Cactoblastis from South America to Australia. While in Australia he also played a prominent part in the Royal 